\title{
PHYSICAL AND MECHANICAL PROPERTIES OF WOOD FROM INVASIVE TREE SPECIES
}

\author{
Komán Szabolcs ${ }^{1, \$}$ \\ https://orcid.org/0000-0001-9511-0277
}

David Varga ${ }^{2}$

\begin{abstract}
Because invasive tree species are being suppressed all over the world, there is a lack of basic information needed for their use in the processing industry. One piece of important information for woodworking applications is the air-dry density, which is $653 \mathrm{~kg} / \mathrm{m}^{3}$ in the case of tree of heaven (Ailanthus altissima), $536 \mathrm{~kg} / \mathrm{m}^{3}$ for box elder (Acer negundo), and $702 \mathrm{~kg} / \mathrm{m}^{3}$ for green ash (Fraxinus pennsylvanica). The order of the 3 species is the same for oven-dry and basic density. In terms of compression and bending, tree of heaven has higher values than green ash. Because the strength of the tree of heaven and the green ash are largely the same as the common ash (Fraxinus excelsior), it can be replaced by these tree species. The properties of box elder wood are significantly different from those of sycamore (Acer pseudoplatanus), so this tree species is not suitable for replacement.
\end{abstract}

Keywords: Box elder, green ash, invasive species, tree of heaven, wood density, wood mechanical properties.

\section{INTRODUCTION}

Climate change influences the range and occurrence patterns of both native and non-native species. The spread of invasive plant species and their habitat conversion effects are a major environmental problem. A significant proportion of these species are woody plants (Ónodi 2016). The term invasive species has various meanings. By the most common definition, biological invasion means the spread of a non-native (alien) species. For example, according to the International Union for Conservation of Nature (IUCN) definition, only non-native species that endanger the biodiversity of natural areas are included in this group (Csiszár 2012).

With regard to species invasiveness, the success of invasive species is largely due to their superiority over native species in terms of growth rate and spread into recipient ecosystems. This superiority is related to higher values of traits related to fitness such as growth rate, maturity age, fecundity, and seed dispersal (Porté et al. 2011). Beside climatic changes, invasive species are currently considered one of the biggest threats to biodiversity. The ease of travel and the nature of global economy have been the major drivers of species introductions. This is unlikely to change as there do not appear to be any realistic scenarios that would reduce activities related to travelling and trade, which could consequently result in a decreased number of new introductions (Krumm and Vitková 2016).

Density is an important physical property of the usability of the wood. From it one can also infer the strength properties (Kiaei 2013). There is typically a very strong relationship between density and modulus of rupture (MOR) and modulus of elasticity (MOE) as shown in Zhang (1997). Additionally, basic density is closely related to end-use quality parameters, such as cellulose yield and strength of building materials (Harvald 
and Olesen 1987). Higher density species of wood usually have more solid wood than lower density species. Knowing the value of basic density is important, especially regarding the determination of wood-chip bulk density, pulp production, or in particleboard manufacturing. The specific gravity (SG) of wood is a measure of the amount of structural material a tree species allocates to support and strength. In recent years, wood specific gravity, traditionally a forester's variable, has become the domain of ecologists exploring the universality of plant functional traits and conservationists estimating global carbon stocks (Williamson and Wiemann 2010).

Information about the feature of the wood is important in regards usage of invasive tree species. Therefore, the main purpose of this study is to explore the basic woody properties of the 3 invasive tree species found worldwide.

\section{Tree of heaven (Ailanthus altissima)}

Tree of heaven was originally introduced in Europe (18th century) as an amenity tree and as forage for silk worms. Its use as an ornamental and shade tree however continues today in Europe. Further uses include plantations for erosion control on slopes, verges of traffic lanes, dunes on the coast, afforestation or reforestation, reclamation of landfill sites, and mine spoils (Kowarik and Säumel 2007). It grows on a wide range of soils, from poor to rich and from dry to moist. Tree of Heaven tolerates relatively high levels of air pollution and may be able to sequester some pollutants. For this reason, it has been widely planted in urban areas worldwide to reduce environmental pollution (Baptista et al. 2014).

Tree of heaven has been used also for the biomass production of fuel wood and for the production of fodder for goats and cattle (Feret 1985, Baptista et al. 2014), making it a promising alternative to cellulose in papermaking.

\section{Green ash (Fraxinus pennsylvanica)}

Green ash is one among the most rapidly spreading woody non-native species in Central Europe during the past 25 years (Drescher and Prots 2016). The green ash is early- to late-succession species of riparian forests, adapted to survive in flooded soils through a variety of physiological and morphological traits. In Central Europe, it is mainly observed in riparian mixed forests of Quercus robur, Ulmus spp. and Fraxinus excelsior, along the great rivers (Branquart et al. 2010).

Green ash wood is strong, durable, and shock-resistant. As such, it is valuable for making specialty items, like tool handles and baseball bats. Its appropriate form and suitability as a shade tree have made green ash a popular ornamental tree and it is widely planted as a parkway-and street tree in urban and suburban areas throughout the US and abroad (Kovacs et al. 2010). The wood has lower quality in comparison with the common ash, and especially timber plantations rarely can be found. Higher wood quality, compared to common ash, can be found on drier sites where tree growth is slower. In the north-west of Turkey, where narrow-leaved ash is more widespread in fast-growing plantations on swampy lowlands, the wood quality is more similar to one of the poplars and is suitable for pulpwood and bonded wood products, such as plywood, laminated veneer lumber and glued laminated timber. Leaves are eatable regarding livestock, and in southern Europe, this ash was traditionally used as a fodder tree. It is also widely used as an ornamental tree in cities and along roads (Caudullo and Houston 2016).

\section{Box elder (Acer negundo)}

Box elder was brought to Europe in the XVII century as a decorative tree. Currently, it is widely spread and belongs to serious invasive-type species (Ednich et al. 2015).

Box elder is used as timber to produce boxes, furniture of low quality and fencing, as its wood is of no high commercial value and is relatively infirm. It can also be used to create horticultural plantations and landscape plantings. This species was previously used in the US to control wind erosion and it is mainly used for this purpose across the globe. Like other maple species, its sap can be used as a raw material for producing a syrup, known as ,mountain molasses'. The species is more considered as firewood but is still occasionally used as fuel (Barstow et al. 2017). 


\section{MATERIALS AND METHODS}

The specimens used for the study were cut from 3 trunks per tree species. Tree of heaven (Ailanthus altissima (Mill.) Swingle) were 41 years old, box elder (Acer negundo L.) were 45 years old, the green ash (Fraxinus pennsylvanica Marsh.) were 48 years old. Mixed samples were taken from the sapwood and heartwood in order to represent the average species features. From the examined trunk the following properties were defined based on the relevant standards: density (DIN 68364, 2003), compression strength (DIN 52185, 1976), tensile strength (DIN 52188, 1979), static bending strength (DIN 52186, 1978), modulus of elasticity (DIN 68364, 2003), and impact bending strength (DIN 52189, 1981).

The tests were carried out on specimens stored under normal climate conditions $\left(\mathrm{T}=20^{\circ} \mathrm{C} ; \varphi=65 \%\right)$ until equilibrium moisture was reached. Storage time lasted till the samples has reached constant weight. The strength tests were performed using the Instron 4208 universal material tester (Norwood, USA) and Charpy impact tester (Leominster, England). 25 pcs of test samples were used in each and every examination cases.

A one-way analysis of variance (ANOVA) of the strengths was performed with the SPSS (IBM, Armonk, NY, USA) software. The statistical significance was set at $\mathrm{p}<0,05$.

\section{RESULTS AND DISCUSSION}

The average density values of the 3 tree species were distinct (Table 1). Regardless of the density type green ash had the highest density among the species followed by the tree of heaven then the box elder. It is worth to compare the values within the species with same genus and also which are more frequently used in the wood industry. Following this principle box elder was compared to sycamore (Acer pseudoplatanus), green ash was compared to common ash (Fraxinus excelsior). As the tree of heaven's wood is most closely related to ash, common ash were chosen in its case too.

One of the most important characteristics when selecting wood species for wood-paper and energy purposes is knowing the different types of densities. Green ash has an air dry density of $702 \mathrm{~kg} / \mathrm{m}^{3}$, it is almost $10 \%$ higher than those mentioned by Meier (2015), while having nearly the same basic density. The test results correspond to the density of the common ash (Wagenführ 2007, Sopushynskyy and Teischinger 2013, Meier 2015, Diler 2017, Giagli et al. 2018), making the wood characteristics very similar.

The air-dry density of the tree of heaven is the same as reported by Požgaj et al. (1997) and Surmiński (1995), but is significantly higher than that reported by Wagenführ (2007). The values of basic and oven-dry density are significantly below those measured by Miao et al. (2014), while exceeding those published by Kúdela and Mamonova (2006). Compared to common ash, regarding all three densities, it is less.

Table 1: Density values of the examined tree species.

\begin{tabular}{|c|c|c|c|c|c|c|c|c|c|c|c|c|}
\hline $\begin{array}{c}\text { Density } \\
\text { type }\end{array}$ & \multicolumn{4}{|c|}{ Green ash } & \multicolumn{4}{c|}{ Box elder } & \multicolumn{3}{c|}{ Tree of heaven } \\
\cline { 2 - 13 } & Avg & Min. & Max. & St. Dev. & Avg. & Min. & Max. & St. Dev. & Avg. & Min. & Max. & St. Dev. \\
\hline $\begin{array}{c}\text { Oven-dry } \\
\mathrm{u}=0 \% \\
\left(\mathrm{~kg} / \mathrm{m}^{3}\right)\end{array}$ & 628 & 562 & 685 & 34 & 495 & 459 & 541 & 21 & 608 & 545 & 652 & 29 \\
\hline $\begin{array}{c}\text { Air-dry } \\
\mathrm{u}=12 \% \\
\left(\mathrm{~kg} / \mathrm{m}^{3}\right)\end{array}$ & 702 & 647 & 756 & 31 & 536 & 501 & 579 & 22 & 653 & 611 & 695 & 21 \\
\hline $\begin{array}{c}\text { Basic } \\
\left(\mathrm{kg} / \mathrm{m}^{3}\right)\end{array}$ & 550 & 510 & 593 & 20 & 444 & 412 & 474 & 19 & 531 & 497 & 571 & 20 \\
\hline
\end{tabular}


In the case of the box elder, the test results are the same as the literature average (Meier 2015). According to the processed literature (Wagenführ 2007, Meier 2015, Hassan and Tippner 2019), however, the value of air-dry density may be up to $15 \%$ lower than that of sycamore. A smaller difference can be observed for the basic density and a larger difference for the oven-dry density.

The order of density values between the three species varies slightly in the case of compressive strength (Figure 1). With the lowest density, the box elder also has the lowest compression strength of $37,1 \mathrm{MPa}$, which corresponds to what Meier (2015) mentioned. However, it is significantly lower than the value of sycamore (Wagenführ 2007, Meier 2015). The highest density green ash has a compressive strength of 46,2 MPa, lower than that of the tree of heaven $(53,4 \mathrm{MPa})$, which has a lower density. In the case of green ash, the value obtained is the same as that reported by Alden (1995), while it is much higher than that of Meiere (2015). The same can be said of the tree of heaven, where the measured value is almost identical to Berki (2014), but exceeds that of Alden (1995). The compressive strength of common ash (Wagenführ 2007, Meier 2015) is virtually identical to that of the tree of heaven.

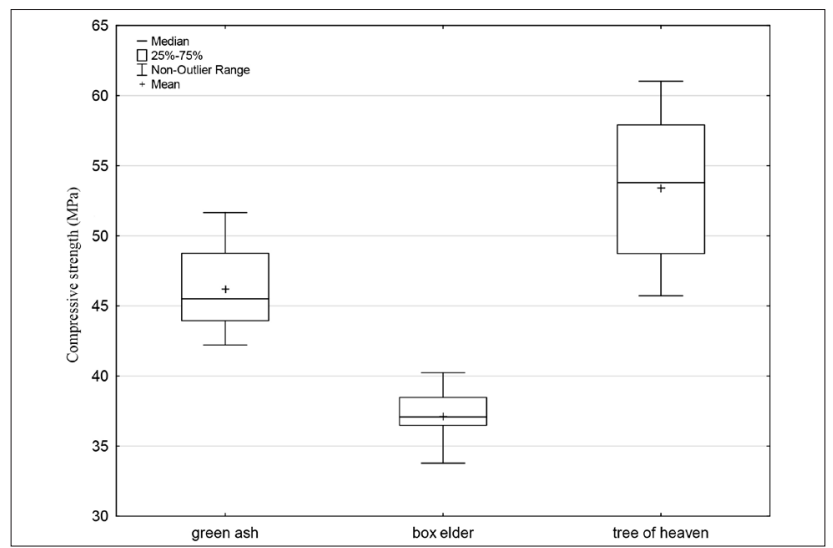

Figure 1: Compressive strength of the species tested.

The order of species for the MOR (Figure 2) is the same as that of compressive strength. The highest of these is the tree of heaven (111,7 MPa), which is $25 \%$ higher than previously reported (Alden 1995, Berki 2014, Meier 2015). With a value of $75,4 \mathrm{MPa}$, the box elder has the smallest MOR, which in turn is also $25 \%$ higher than what Meier mentions. Green ash is located between the two species with a value of $97,9 \mathrm{MPa}$, which is in complete agreement with Meier (2015) and Alden (1995). The bending strength of the box elder does not reach the value of sycamore. The green ash's is just below, while the tree of heaven's is just above the value of the common ash.

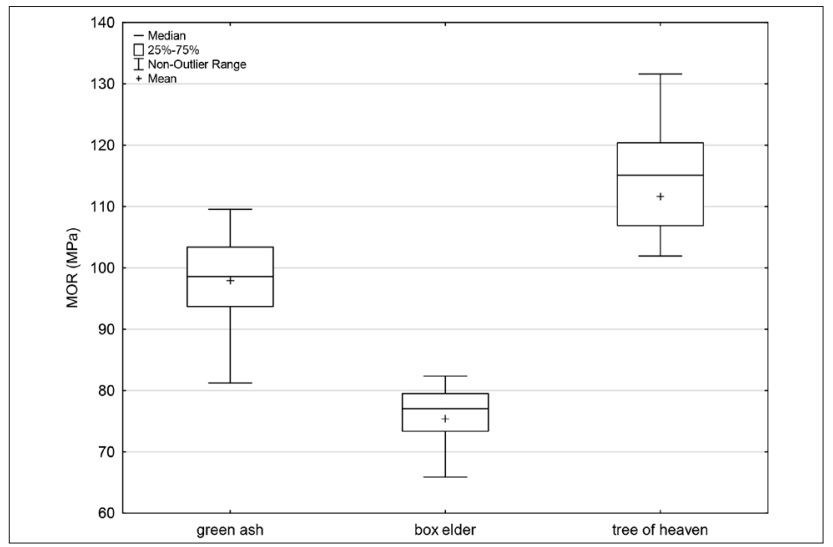

Figure 2: Modulus of rupture of the examined tree species. 
For MOE, the order is as follows (Figure 3): tree of heaven (11665 MPa), green ash (9546 MPa), and box elder (6989 MPa). The tree of heaven and box elder values do not differ significantly from those given by the literature (Meier 2015, Alden 1995). Green ash, on the other hand, has a value more than $15 \%$ higher than those reported. In terms of MOE, wood from tree of heaven and green ash is virtually equivalent to common ash, whereas the value of the box elder was more than 20\% lower than Wagenführ (2007), Meier (2015), Hassan and Tippner (2019) reported.

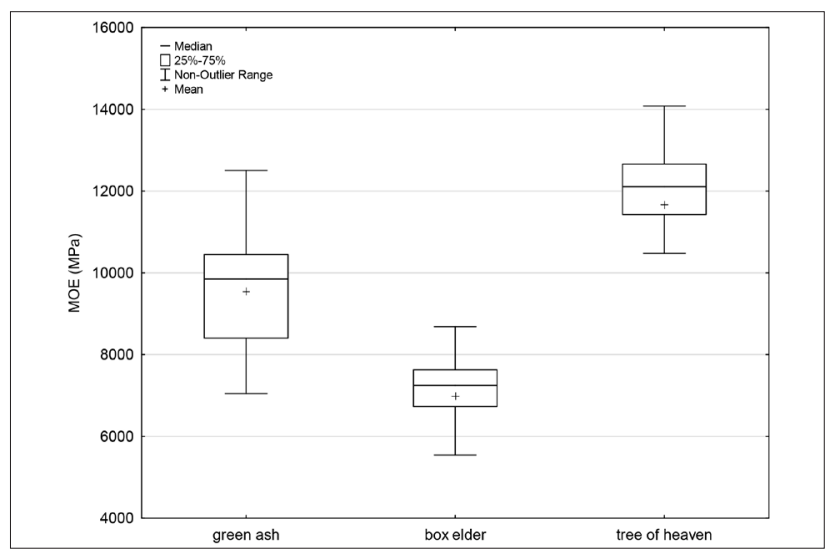

Figure 3: Modulus of elasticity of the examined tree species.

The impact bending strength of the tree species (Figure 4) follows the order of density. The highest value was the green ash $\left(7,97 \mathrm{~J} / \mathrm{cm}^{2}\right)$, followed by the tree of heaven $\left(6,11 \mathrm{~J} / \mathrm{cm}^{2}\right)$ and box elder $\left(2,78 \mathrm{~J} / \mathrm{cm}^{2}\right)$. Regarding the test results, it should be noted that the standard deviation values are highest for this strength type. This characteristic is rarely determined when testing the basic strength properties, so it is difficult to compare it with other literature values. Only Berki (2014) mentions this in the case of tree of heaven, compared to which the test results were $25 \%$ lower. Green ash exceeded impact bending strength of common ash, while tree of heaven was below it. For the box elder, this feature was less than half that of a sycamore.

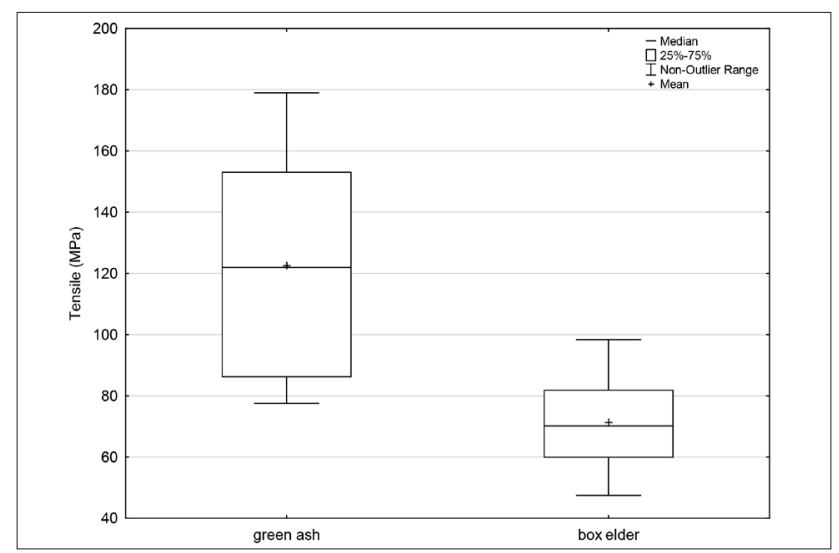

Figure 4: The impact bending strength of the examined tree species.

The tensile strength was determined for 2 species (Figure 5), which also had high variance values. Similar to impact bending strength, very few studies report this strength characteristic. The tensile value is $122,6 \mathrm{MPa}$ for green ash and 71,3 MPa for box elder. Compared to Berki (2014) common ash value, green ash is about 
$25 \%$ lower.

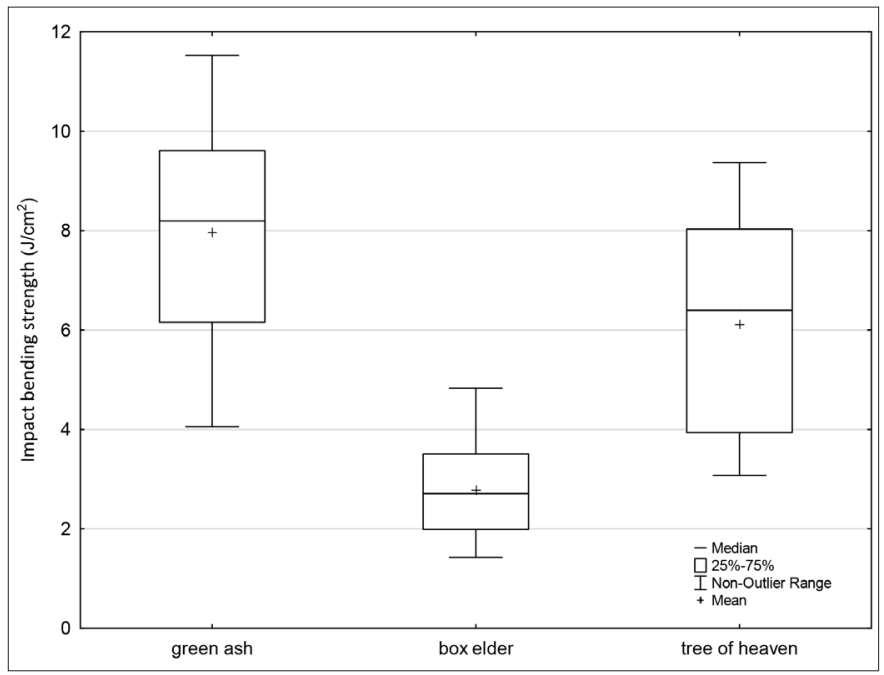

Figure 5: The tensile strength of the examined tree species.

\section{CONCLUSIONS}

Regardless of the density type, green ash has the highest value among the invasive tree species examined, followed by the tree of heaven and then box elder. In terms of air-dry density, green ash wood is the same as common ash's, while the tree of heaven is less. Box elder wood, in terms of density, is below that of sycamore.

Despite the fact that green ash has a higher density, regarding MOR, MOE, and compression strength, tree of heaven has higher strength values.

Green ash for density regarding MOE and impact bending strength, while tree of heaven regarding MOR, MOE, and compression have values approximately equal to common ash. Therefore, regarding these characteristics, the common ash can be replaced by the studied tree species.

The box elder lags behind the sycamore for all strength characteristics and is therefore not a substitute for this type of stress.

\section{REFERENCES}

Alden, H.A. 1995. Hardwoods of North America.Gen. Tech. Rep. FPL-GTR83. U.S. Department of Agriculture, Forest Products Laboratory: Madison, WI., USA. https://www.fpl.fs.fed.us/documnts/fplgtr/fplgtr83.pdf

Baptista, P.; Costa, A.P.; Simões, R.M.; Amaral, M.E. 2014. Ailanthus altissima: An alternative fiber source for papermaking. Ind Crops Prod 52:32-37. https://doi.org/10.1016/j.indcrop.2013.10.008

Barstow, M.; Crowley, D.; Rivers, M.C. 2017. Acer negundo. The IUCN Red List of threatened species 2017.e.T62940A3117065. https://dx.doi.org/10.2305/IUCN.UK.2017-3.RLTS.T62940A3117065.en 
Berki, D. 2014. Eigenschaften und Verwendung des Holzes des Götterbaums (Ailanthus altissima). Master's Thesis, Universität für Bodenkultur Wien, Institut für Holztechnologie und nachwachsende Rohstoffe, Vienna, Austria. https://litsearch.boku.ac.at/primo-explore/fulldisplay?docid=BOK_alma2136586230003345\&context $=$ L\&vid $=$ BOK\&lang $=$ de_DE

Branquart, E.; Vanderhoeven, S.; Van Landuyt, W.; Van Rossum, F.; Verloove, F. 2010. Harmonia database: < Fraxinus pennsylvanica $>$. Harmonia version 1.2. Belgian Forum on Invasive Species. https://ias.biodiversity.be/species/show/134

Caudullo, G.; Houston Durrant, T. 2016. Fraxinus angustifolia in Europe: distribution, habitat, usage and threats. In Online European Atlas of Forest Tree Species. Ayanz, J.; de Rigo, D.; Caudullo, G.; Houston Durrant, T.; Mauri, A. (eds.). FISE Comm. Publications Office of the European Union: Luxembourg. https://forest.jrc.ec.europa.eu/media/atlas/Fraxinus_angustifolia.pdf

Csiszár, Á.; Tiborcz, V. 2012. A fejezetek összeállításának és a fajok jellemzésének szempontjai. In Inváziós növényfajok Magyarországon (in Hungarian). Csiszár, Nyugat-magyarországi Egyetem Kiadó: Sopron, Hungary.https://mek.oszk.hu/11700/11738/11738.pdf

DIN. 1979. Testing of wood - Determination of ultimate tensile stress parallel to grain. DIN. 52188. 1979. Deutsches Institut für Normung: Berlin, Germany.

DIN. 2003. Properties of wood species - Density, modulus of elasticity and strength. DIN. 68364. 2003. Deutsches Institut für Normung: Berlin, Germany.

DIN. 1978. Testing of wood - Bending test. DIN. 52186. 1978. Deutsches Institut für Normung: Berlin, Germany.

DIN. 1981. Testing of wood - Determination of impact bending strength. DIN. 52189. 1981. Deutsches Institut für Normung: Berlin, Germany.

DIN. 1976. Testing of wood - Compression test parallel to grain. DIN. 52185. 1976. Deutsches Institut für Normung: Berlin, Germany.

Diler, H.; Acar, M.E.; Balıkçı, E.; Demirci, S.; Erdil, Y.Z. 2017. Withdrawal force capacity of T-Type furniture joints constructed from various heat-treated wood species. BioResources 12(4): 7466-7478. https://bioresources.cnr.ncsu.edu/resources/withdrawal-force-capacity-of-t-type-furniture-joints-constructed-from-various-heat-treated-wood-species/

Drescher, A.; Prots, B. 2016. Fraxinus pennsylvanica - an invasive tree species in Middle Europe: Case studies from the Danube basin. Contributii Botanice LI: 55-69. http://contributii_botanice.reviste.ubbcluj.ro/ materiale/2016/Contrib_Bot_vol_51_pp_055-069.pdf

Ednich, E.M.; Chernyavskaya, I.V.; Tolstikova, T.N.; Chitao, S.I. 2015. Biology of the invasive species Acer negundo L. in the conditions of the north-west caucasus foothills. Indian J Sci Technol 8(30): 1-3. https://dx.doi.org/10.17485/ijst/2015/v8i30/85426

Feret, P.P. 1985. Ailanthus: variation, cultivation, and frustration. Arboric Urban For 11(12): 361-368.

Giagli, K.; Baar, J.; Fajstavr, M.; Gryc, V.; Vavrcík, H. 2018. Tree-ring width and variation of wood density in Fraxinus excelsior L. and Quercus robur L., growing in floodplain forests. BioResources 13(1): 804-819. https://bioresources.cnr.ncsu.edu/resources/tree-ring-width-and-variation-of-wood-density-in-fraxinus-excelsior-l-and-quercus-robur-l-growing-in-floodplain-forests/

Harvald, C.; Olesen, P.O. 1987. The variation of the basic density within the juvenile wood of Sitka spruce (Picea sitchensis). Scand J For Res 2(1-4): 525-537. https://doi.org/10.1080/02827588709382488

Hassan, K.; Tippner, J. 2019. Acoustic properties assessment of neem (Azadirachta indica A. Juss.) wood from trees irrigated with secondarily treated wastewater. BioResources 14(2): 2919-2930. https://bioresources. cnr.ncsu.edu/resources/acoustic-properties-assessment-of-neem-azadirachta-indica-a-juss-wood-from-trees-irrigated-with-secondarily-treated-wastewater/ 
Kiaei, M. 2013. Radial variation in wood static bending of naturally and plantation grown alder stems. Cell Chem Technol 47(5-6): 339-344. https://www.cellulosechemtechnol.ro/pdf/CCT5-6(2013)/p.339-344.pdf

Kovacs, K.F.; Haight, R.G.; McCullough, D.G.; Mercader, R.J.; Siegert, N.W.; Liebhold, A.M. 2010. Cost of potential emerald ash borer damage in U.S. communities, 2009-2019. Ecol Econ 69(3): 569-578. https://doi.org/10.1016/j.ecolecon.2009.09.004

Kowarik, I.; Säumel, I. 2007. Biological flora of Central Europe: A. altissima (Mill.) Swingle Perspect. Perspectives in Plant Ecology, Evolution and Systematics 8(4): 207-237. https://doi.org/10.1016/j.ppees.2007.03.002

Krumm, F.; Vítková, L. 2016. Introduced tree species in European forests: opportunities and challenges. European Forest Institute. 423p.

Kúdela, J.; Mamoňová, M. 2006. Tree-of-heaven wood (Ailanthus altissima, Mill.) Structure and properties. In Wood Structure and Properties. Kurjatko, S.; Kúdela, J.; Lagaňa, R. (eds.). Arbora Publishers: Zvolen, Slovakia. pp. 275-280.

Meier, E. 2015. WOOD! Identifying and Using Hundreds of Woods Worldwide. The wood database. https://www.wood-database.com

Miao, X.; Chen, H.; Lang, Q.; Bi, Z.; Zheng, X.; Pu, J. 2014. Characterization of Ailanthus altissima veneer modified by urea-formaldehyde pre-polymer with compression drying. BioResources 9(4): 5928-5939. https://ojs.cnr.ncsu.edu/index.php/BioRes/article/view/BioRes_09_4_5928_Miao_Ailanthus_altissima_Veneer

Ónodi, G. 2016. Az idegenhonos, illetve inváziós fafajok élőhelyformáló hatásai. Erdészettudományi Közlemények 6(2): 101-113. (in Hungarian). https://dx.doi.org/10.17164/EK.2016.008

Porté, A.J.; Lamarque, L.J.; Lortie, C.J.; Michalet, R.; Delzon, S. 2011. Invasive Acer negundo outperforms native species in non-limiting resource environments due to its higher phenotypic plasticity. $B M C$ Ecol 11: 28. https://doi.org/10.1186/1472-6785-11-28

Požgaj, A.; Kurjatko, S.; Chovanec, D.; Babiak, M. 1997. Štruktúra a vlastnosti dreva (in Slovak). Príroda, a.s.: Bratislava, Slovakia. p.488.

Sopushynskyy, I.; Teischinger, A. 2013. Diagnostic features of Fraxinus excelsior L. with wavy-grained wood growing in Ukraine. Forest Research Papers 74(3): 189-195. https://doi.org/10.2478/frp-2013-0018

Surmiński, J. 1995. Właściwości techniczne i możliwości zastosowania drewna jesionowego. In Jesion wyniosty Fraxinus excelsior L. (Nasze Drzewa Leśne 17). Bugała, W. (ed.). Polska Akademia Nauk, Instytut Dendrologii: Sorus, Poznań-Kórnik, Poland. 469-480pp.

Wagenführ, R. 2007. Holzatlas, Wood Atlas. 6th ed., Fachbuchverlag im Carl Hanser Verlag: Leipzig, Germany. (in German).

Williamson, G.B.; Wiemann, M.C. 2010. Measuring wood specific gravity...Correctly. Am J Bot 97(3): 519-524. https://bsapubs.onlinelibrary.wiley.com/doi/full/10.3732/ajb.0900243

Zhang, S.Y. 1997. Wood specific gravity-mechanical property relationship at species level. Wood Sci Technol 31(3): 181-191. https://doi.org/10.1007/BF00705884 